\title{
SIKAP SOSIAL ANGGOTA ORGANISASI PERGERAKAN BOEDI OETOMO: SUATU TINJAUAN HISTORIS
}

\author{
Winahyu Adha Yuniyati ${ }^{a}{ }^{1}$, Leo Agung $S^{b}$, Warto $^{c}$ \\ ${ }^{a}$ Mahasiswa Program Studi Pendidikan Sejarah FKIP-Universitas Sebelas Maret (UNS) \\ ${ }^{b, c}$ Dosen Program Studi Pendidikan Sejarah FKIP-Universitas Sebelas Maret (UNS) \\ Jalan Ir. Sutami 36 A, Surakarta, 57126
}

\begin{abstract}
ABSTRAK
Pergerakan nasional di Indonesia terlaksana pada tahun 1908. Terdapat beberapa organisasi yang didirikan pada masa ini bergerak dibidang sosial. Tujuan penelitian ini untuk menganalisis sikap sosial anggota organisasi Boedi Oetomo selama masa pergerakan. Metode yang digunakan dalam penelitian ini adalah historis, dengan analisis data menggunakan studi kepustakaan. Boedi Oetomo merupakan organisasi pertama yang didirikan pada masa pergerakan nasional di Indonesia. Organisasi ini bergerak di bidang sosial, sebagai akhibat dari tindakan kolonialisme Belanda di Indonesia. Pelaksana organisasi ini adalah kaum terpelajar yang mempunyai sikap sosial yang baik. Dari penelusuran studi pustaka, ditemukan delapan sikap sosial baik yang terdapat pada setiap anggota organisasi Boedi Oetomo yaitu jujur, diisiplin, tanggung jawab, gotong-royong, emansipasi, percaya diri, patuh nilai dan norma, serta sopan santun. Hal ini patut dicontoh, karena generasi saat ini banyak yang tidak mempunyai sikap sosial baik terhadap sesama, sikap individual dan mementingkan kepentingan pribadi sebagai salah satu prioritas kehidupan. Pelaku organisasi Boedi Oetomo saja dapat melaksnakan sikap sosial baik, mengapa kita sebagai penerus bangsa tidak dapat melanjutkan perjuangan pergerakan nasional salah satunya dengan penerapan sikap sosial baik.
\end{abstract}

\section{Kata Kunci: Sikap Sosial, Organisasi, Boedi Oetomo}

\begin{abstract}
Indonesia's National Revolution begun in 1908. There were several organization that was build then that moved in social field. The purpose of this research is to analyze the social attitude of Boedi Oetomo's member throughout the Revolution. Method that was used in this research was historical with data analyzation from literature studies. Boedi Oetome is the first organization that was founded in the National Revolution era. This organization moved in social field, as the result of Dutch's colonialism in Indonesia. The member of this organization was the educated that have good attitudes. From the analyzation of literarure studies it can be seen that every member of Boedi Oetome had eight main good social attitudes which is honesty, discipline, responsible, emancipation, confidence, great team work, obeyed the rules and norms, and politeness. Those attitudes are great examples because now there are many people that don't have good social attitudes toward others, individualistic and putting their own needs before others are their main priorities. Even the member of Boedi Oetomo could have good attitudes, why can't we, as the hope of this country continue the fight of National Revolution by applying good social attitudes.
\end{abstract}

Keywords: Social Attitudes, Organization, Boedi Oetomo

\section{PENDAHULUAN}

Secara de fakto dan de jure Indonesia melaksanakan proklamasi kemerdekaan pada tanggal 17 agustus 1945. Proses untuk mencapai puncak kemerdekaan tersebut tidak mudah.

\footnotetext{
${ }^{1}$ Penulis Koresponden

E-mail address: winahyu_11@yahoo.co.id doi: http://dx.doi.org/10.25157/ja.v4i2.894
}

Terdapat beberapa usaha yang dilaksanakan bangsa Indonesia, seperti yang terjadi pada abad XX, merupakan awal pembentukan jati diri masyarakat Indonesia. Pada masa tersebut banyak perubahan yang muncul baik dari bidang sosial, politik, budaya maupun agama. Beberapa

Copyright@2017 Jurnal Artefak e-ISSN: 2580-0027 
ahli sejarah menyatakan bahwa pada abad tersebut Indonesia mampu melaksanakan pergerakan nasional guna mencapai cita-cita luhur yaitu kemerdekaan. Pergerakan nasional yang dilaksanakan berbeda dengan gerak perlawanan terhadap pemerintah kolonial sebelumnya.

Bentuk perlawanan bangsa Indonesia sebelum abad XX masih sangat tradisional. Bersifat kedaerahan, berpacu pada seorang pemimpin yang kharismatik, pelaksanaan perlawanan secara fisik dan tidak memperhatikan sikap sosial sehingga perlawanan mudah tumbang atau terkalahkan oleh pemerintah kolonial. Hal ini kontras apabila di bandingkan dengan perlawanan setelah abad XX. masyarakat Indonesia lebih memilih untuk melaksanakan diplomasi dengan sikap sosial yang baik.

Sikap sosial yang baik ternyata dapat menyampaikan aspirasi terhadap pemerintah kolonial benlanda. Karena sikap sosial menurut Abu Ahmadi adalah kesadaran individu atau kelompok yang menentukan perbuatan nyata, yang berulang-ulang terhadap objek sosial (2009:149). Sehingga dapat menyatukan pendapat anatara kaum terpelajar yang mewakili bangsa Indonesia dan pejabat kompeni Belanda sebagai objek sosial.

Perubahan pergerakan pada masa ini selain dilatarbelakangi dengan sikap sosial juga adanya peristiwa pada masa sebelumnya yaitu dikenal dengan politik etis. Masa politik etis merupakan penerapan kebijakan trias vande venter sebagai suatu wujud balas budi pejabat kompeni Belanda terhadap Indonesia. Terdapat tiga unsur, diantaranya adalah migrasi sebagai langkah pemerataan penduduk, irigasi sebagai upaya memberikan sumber perairan, dan edukasi merupakan penyetaraan pendidikan bagi masyarakat Indonesia. Dalam beberapa pengertian, politik etis telah menetapkan polapola bukan untuk dua, tiga atau empat dasawarsa, tetapi untuk sebagian besar sisa abad itu (Ricklefs, 2011:246).

Politik etis benar terlaksana di Indonesia pada awal abad XX. Meski pelaksnaan tidak merata bagi seluruh masyarakat Indonesia dengan kata lain hanya pada keturunan priyayi, namun membawa pengaruh besar bagi perkembangan zaman di Indonesia. Penerapan edukasi sebagai penyetaraan pendidikan menjadi salah satu faktor utama dalam perubahan zaman di Indonesia, yaitu menyebabkan lahirnya kaum terpelajar. Sekelompok masyarakat melek huruf yang mengetahui perkembangan dunia luas. Seperti pendapat Ricklefs (2011) menyatakan bahwa pendidikan tidak menghasilkan elit baru yang tahu terimakasih dan mau bekerja sama dengan Belanda, hanya semangat yang berkobar-kobar di kalangan rakyat (hlm. 242).

Munculnya kaum melek huruf atau kaum terpelajar di Indonesia banyak menyebabkan munculnya pergerakan. Pergerakan yang didirikan dengan cita-cita untuk merubah nasib masyarakat Indonesia. Masyarakat Indonesia sudah lama hidup dalam belenggu kolonialisme, yaitu suatu pergerakan yang dilaksanakan oleh pemerintah kolonial hindia Belanda di Indonesia. Keinginan luhur kaum terpelajar mendorong terlaksananya pergerakan secara bersama yaitu pergerakan nasional.

Faktor lain yang menyebabkan munculnya pergerakan nasional di Indonesia dilaksanakan oleh kaum terpelajar adalah kenangan akan kejayaan masa lampau. Dibuktikan Gamal Komandoko dalam tulisannya, bahwa bangsa Jawa telah mencapai kemajuan luar biasa, semisal telah menghasilkan berbagai mahakarya bangunan yang menunjukkan ketinggian kebudayaan dan teknologi pada zaman Hindu-Budha (hlm. 33). Indonesia pernah berjaya dan terkenal hingga di seluruh penjuru dunia. Indonesia terkenal dengan kerajaan-kerajaan besar, seperti kerjaan Majapahir, Mataram, Sriwijaya dan sebagainya yang kaya dan termasyur bahkan menjalin hubungan dengan negara-negara lain pada masanya. Kejayaan seperti inilah yang diinginkan para kaum terpelajar untuk mengentaskan masyarakat nusantara dari belenggu penjajahan pejabat kompeni Belanda.

Disamping kejayaan masa lampau juga adanya persamaan nasib, yaitu sama-sama terkena kerasnya tindasan pemerintah kolonialisme. Kaum terpelajar yang sadar akan nasib bangsa Indonesia mulai berkumpul dan membahas nasib bangsa Indonesia yang sejak lama tertidas akan kependudukan bangsa asing. Mereka sadar bahwa sesungguhnya Indonesia kaya akan sumber daya alam yang melimpah. Hasil alam di Indonesia hampir secara keseluruhan sudah sejak lama diambil oleh bangsa asing, bahkan bangsa Indonesia hampir tidak menikmati hasil alam sedikitpun. Sudah waktunya bangsa Indonesia sadar akan kerasnya kolonialisme bangsa Asing di Indonesia. Hal ini sejalan dengan ungkapan singkat dari George D. Larsen (1990) yang menyatakan bahwa 
kesadaran nasional Jawa yang tiba-tiba tergugah (hlm. 57).

Banyak orang mengatakan bahwa Indonesia adalah tanah surga, hasil alam melimpah yang laku di pasaran internasional. Hanya saja masyarakat Indonesia belum mengetahui cara untuk memanfaatkan dan menggunakan hasil alam tersebut agar dapat tepat guna. Hasil alam termasuk budaya yang harus dilestarikan (Alfian, 2013: 424). Nilai budaya di sebuah wilayah sangat dominan dan kuat tertanam pada diri seseorang sehingga membentuk karakter seseorang. Selanjutnya tugas tokoh terpelajarlah yang saat itu mulai berkumpul dan membahas bagaimana caranya agar dapat segera keluar dari belenggu kolonialisme bangsa asing di Indonesia. Langkah tokoh terpelajar tentu tidak mudah, perlu adanya usaha nyata agar tidak serta merta menyinggung secara langsung kedudukan pejabat kompeni Belanda di Indonesia.

Perkumpulan dan perserikatan kaum terpelajar mulai dilaksanakan pada tahun 1908. Pada beberapa perkumpulan membahas tentang hak dan status sebagai masyarakat. Mereka yang mengetahui kehidupan masyarakat merdeka di luar negeri mulai dapat membandingkan beberapa masalah yang dihadapi masyarakat Indonesia. Kaum terpelajar mulai banyak yang mengetahui perkembangan dunia dari berbagai pengalaman.

Seperti munculnya paham-paham baru dunia yang diterapkan dengan bebas di berbagai negara merdeka. Keberhasilan pergerakan nasional di negara-negara Asia Afrika, negaranegara yang mempunyai nasib dan kemampuan sama dengan masyarakat Indonesia mulai bangkit dan memerdekakan diri dari belenggu kolonialisme bangsa asing. Selanjutnya juga adanya kemenangan Jepang atas Rusia pada tahun 1905, yang menjadikan tonggak semangat bangsa Indonesia untuk berjuang melawan bangsa asing seperti Jepang. Apabila mengutip pendapat Wahidin Sudirohoesodo dalam Gamal Komandoko (2008) bahawa masyarakat Jawa akan bangkit meraih kegemilangannya kembali jika mendapatkan pendidikan modern dengan tidak melupakan akar budayanya selaku bangsa Jawa (hlm. 37).

Berbagai latar belakang tersebut maka kaum terpelajar memberanikan diri untuk memperjuangkan nasib bangsa Indonesia. Dengan sikap jujur dan toleransi dengan sesama kaum terpelajar mulai membentuk perkumpulan atau organisasi. Organisasi pergerakan kaum terpelajar pertama di bentuk adalah Boedi Oetomo. Seperti pendapat Gamal Komandoko (2008: 21) bahwa Boedi Oetomo disebut organisasi modern Indonesia pertama yang dibentuk dengan cara barat. Organisasi ini di bentuk dengan asas sosial, yaitu berkeinginan untuk merubah nasib masyarakat Indonesia. Pelaksana organisasi ini adalah kaum terpelajar yang sedang menduduki bangku kuliah di STOVIA.

Semangat toleransi dengan sesama menjadi salah satu landasan penting berdirinya organisasi pergerakan nasional. Sikap sosial yang baik selalu ditunjukkan kepada siapa saja, baik kepada sesama dan objek sosial yaitu pejabat kompeni Belanda. Sehingga pergerakannya dalam kubu organisasi pergerakan Boedi Oetomo mendapatkan izin dari pejabat kompeni Belanda. Terhadap pemerintah, Boedi Oetomo berlaku "manis" yang membuat pemerintah pun bersikap "manis" padanyayang membuat Tjipto Mangoenkoesoemo dengan keras menuduh Boedi Oetomo sebagai organisasi yang diberi hati oleh pemerintah (Gamal Komandoko, 2008: 103).

Dukungan pejabat kompeni Belanda menjadi modal utama Boedi Oetomo untuk membentuk organisasi pergerakan. Meski organisasi dibentuk untuk merubah nasib masyarakat Indonesia dari belenggu kolonialisme, namun organisasi ini tetap menjalin hubungan dengan pemerintah dengan sikap soasial yang baik. Hal ini dilaksanakan agar tidak ada larangan pergerakan bagi kaum terpelajar utamanya dalam organisasi pergerakan Boedi Oetomo guna merubah nasib mayarakat Indonesia khususnya pada bidang sosial dan pendidikan.

\section{METODE PENELITIAN}

Metode penelitian yang dilaksanakan oleh penulis mengenai sikap sosial anggota organisasi pergerakan Boedi Oetomo adalah metode historis atau metode sejarah, dengan analisis data menggunakan studi kepustakaan. Seperti yang disampaikan Louis Gottchalk (1983) cara menguji juga menganalisis kesaksian sejarah untuk menemukan data yang valid, otentik dan dapat dipercaya, serta usaha sintetis atas data semacam itu menjadi kisah sejarah yang kredibel. (hlm: 32). 
Bentuk penelitian dengan mengumpulkan data sejarah, dan diperdalam dengan studi kepustakaan. Proses tersebut berdasarkan sintak atau urutan seperti yang dituliskan Ismaun (1984) metode sejarah atau metode historis ini mengandung empat langkah penting atau teknik sebagai berikut : (1) Heuristik merupakan langkah permulaan bagi penulis dalam proses mencari juga mengumpulkan bahan-bahan informasi yang diperlukan yang berhubungan dengan permasalahan penulisan jurnal ilmiah. (2) Kritik, kritik sejarah ialah penilaian kritis kepada data juga fakta sejarah yang sudah ada. Data juga fakta sejarah diproses menggunakan kritik sejarah. Hasilnya disebut bukti (evidence) sejarah. Bukti sejarah ialah kumpulan fakta dan informasi yang telah divalidasi, menjadi terpercaya sebagai bukti dasar yang baik guna menguji kemudian menginterpretasikan suatu permasalahan. (3) Interpretasi, ialah interpretasi (penafsiran) analisis terhadap data juga fakta yang terkumpul. Prosedur ini digunakan untuk menafsirkan data dan fakta, menghubungkan berbagai data dan fakta serta membuat tafsirannya. (4) Historiografi, merupakan langkah setelah melakukan tahap-tahap didalam metode sejarah yakni mengumpulkan data, kritik data dan interpretasi maka sebagai tahap terakhir dari metode sejarah adalah penulisan sejarah (hlm. 94).

\section{HASIL PENELITIAN DAN PEMBAHASAN}

\section{Awal Pendirian Boedi Oetomo}

Sejarah menuliskan bahwa pergerakan nasional di Indonesia lahir dan berkembang sejak tahun 1908. Pergerakan masyarakat Indonesia untuk mencapai kemerdekaan. Hal ini ditandai dengan berdirinya organisasi pergerakan nasional pertama di Indonesia yaitu Boedi Oetomo. Organisasi pergerkan nasional ini didirikan pada 20 Mei 1908 (Gamal Komandoko, 2008:46). Tanggal tersebut menjadi tolok ukur dimulainya pergerakan nasional, bahkan setiap tanggal 20 Mei diperingati sebagai hari kebangkitan nasional.

Organisasi pergerakan Boedi Oetomo didirikan oleh para mahasiswa kedokteran STOVIA di Batavia. R.A.A.A Djajaningrat dalam Nagazumi (1989) menyebutkan bahwa tokoh muda STOVIA yang paling banyak jasanya bagi berdirinya organisasi pergerakan Boedi Oetomo adalah Soetomo, Goenawan Mangoenkoesoemo, Soewarno, Goembreg,
Mohammad Saleh, dan Soelaeman (hlm. 10). Diantara beberapa tokoh pendiri tersebut yang paling besar perannya dalam organisa adalah Soetomo.

Seluruh pendiri organisasi pergerakan Boedi Oetomo awalnya hanya beberapa orang mahasiswa kedokteran STOVIA yang mempunyai cita-cita untuk merubah nasib bangsa Indonesia. Mereka adalah sekelompok orang yang mempunyai sikap sosial yang baik. Mereka berserikat dan berkumpul untuk mendirikan organisasi pergerakan yang diharapkan mampu merealisasikan cita-cita luhur yaitu merubah nasib bangsa Indonesia dari belenggu penjajahan bangsa asing.

Pergerakan tokoh organisasi pergerakan Boedi Oetomo dimulai saat kehadiran tokoh bernama Wahidin Soedirohoesodo yang melakukan aksi mencoba untuk menggugah kesadaran orang-orang Jawa yang mempunyai pengaruh untuk mendukung gagasannya guna merubah nasib bangsa Indonesia (Gamal Komandoko, 2008: 40). Beliau adalah seorang priyayi rendahan dengan gelar dokter Djawa yang secara kepangkatan dalam pemerintahan tidak lebih sebagai asisten wedana (Nagazumi, 1989: 41). Kehadiran Wahidin ke STOVIA selain memberikan dorongan organisasi juga memberikan banyak pandangan tentang kemajuan pendidikan melalui organisasi pergerakan.

Berdasarkan dorongan dan semangat dari Wahidin Soedirohoesodo, Sutomo dan temanteman penggerak organisasi bergegas mengumumkan gerak organisasi pergerakan Boedi Oetomo tersebut. Gerak pertama kalinya adalah melaksanakan perkumpulan secara interen pelaksana organisasi. Dalam perkumpulan tersebut membahas tentang bagaimana caranya untuk membesarkan Boedi Oetomo agar dapat tumbuh dan merealisasikan cita-cita para anggota, terlebih diperbolehkan bergerak oleh pemerintah kolonial.

Usaha para anggota organisasi pergerakan Boedi Oetomo untuk membesarkan organisasi adalah dengan menjalin hubungan dengan sekolah lain. Usaha mereka membuahkan hasil, 3 dari 8 sekolah yang menjadi saksi lahirnya Boedi Oetomo menyatakan akan mendirikan cabang organisasi pergerakan Boedi Oetomo di sekolah masing-masing (Gamal Komandoko, 2008: 47). Sekolah tersebut adalah OSVIA Magelang, Sekoalah Pendidikan Guru (Normaalshcool) Yogyakarta dan Sekolah Menengah Petang (Hogere Burgershool) 
Surabaya. Dengan demikian organisasi pergerakan Boedi Oetomo selanjutnya bertambah luas, dan apabila ditinjau dari segi keanggotaan tercatatat lebih banyak dibandingkan dengan sebelumnya. Sebelum pelaksanaan kongres tercatat terdapat 650 orang anggota organisasi pergerakan Boedi Oetomo. Seluruh anggotanya adalah mahasiswa, baik dari STOVIA maupun dari cabang yang lain.

Selain memperluas keeanggotaan organisasi dari kubu mahasiswa, para pendiri Boedi Oetomo juga berusaha menjalin hubungan dengan para priyayi. Seperti halnya Wahidin mendekati para priyayi tinggi untuk mendapatkan dukungan (Nagazumi, 1989:56). Hubungan anatara pengurus dengan para priyayi terlaksanaka sangat baik, sebab para pengurus menjalin hubungan dengan sikap sosial yang baik. Sehingga keberadaan organisai ini selanjutnya juga mendapatkan izin dari pejabat kompeni Belanda.

Dengan usaha dan semangat yang dilaksanakan pengurus organisasi pergerakan Boedi Oetomo, selanjutnya terlaksanalah rapat pertama kali sebelum kongres. Pada tanggal 8 Agustus 1908 organisasi pergerakan Boedi Oetomo mengadakan rapat kedua di STOVIA (Gamal Komandoko, 2008: 49). Tasa tanggung jawab, toleransi dan emansipasi selalu diutamakan oleh para pengurus Boedi Oetomo, sehingga rapat dapat menghasilkan beberapa putusan mengenai pelaksanaan kongres, dianataranya adalah: (1) Yogyakarta ditentukan sebagai tempat pelaksanaan; (2) kongres terbuka oleh umum; (3) setiap cabang diminta untuk mengirimkan minimal 1 wakilnya; (4) menyetujui bahwa Wahidin Soedirohoesodo sebagai ketua kongres (Robert Van Niel, 1984).

\section{Kongres Pertama dan Keua Boedi Oetomo}

Perbedaan yang mencolok tampak pada pelaksanaan kongres pertama dan kedua. Sikap sosial yang ditunjukkan para anggota organisasi pergerakan Boedi Oetomo pada kongres pertama tampak loyal terhadap cita-cita ingin merubah nasib bangsa Indonesia. Perubahan nasib bangsa Indonesia khususnya pada bidang sosial dan pendidikan. Keberhasilan pendidikan di Indonesuia yaitu dengan tercapainya tujuan nasional (Wijayanti, 2017: 59). Berbeda dengan kongres yang kedua sikap sosial para anggota organisasi hanya tampak menjalankan tugas dari pejabat kompeni Belanda.

\section{a. Kongres Pertama Organisasi pergerakan Boedi Oetomo}

Kongres pertama Boedi Oetomo terlaksana pada tanggal 3 hingga 5 Oktober 1908. Diselenggarakan di Yogyakarta yaitu pada Sekolah Pendidikan Guru atau pada salah satu kantor cabang organisasi pergerakan Boedi Oetomo. Dihadiri seluruh tamu undangan sebanyak 300 orang, dari berbagai kalangan.

Pengurus mengundang berbagai kalangan masyarakat nusantara, baik dari remaja radikal, mahasiswa, priyayi kelas rendah, priyayi kelas tinggi dan perwakilan dari pejabat kompeni Belanda. Hal ini dilaksanakan karena sesuai dengan agenda kongres, yaitu menghimpun seluruh aspirasi masyarakat Indonesia dengan tidak membeda-bedakan suku ras dan agama. Selain itu para bupati atau pejabat pemerintah yang tidak hadir juga menyatakan simpatinya dengan mengirimkan surat maupun utusan (Gamal Komandoko, 2008:60-61).

Pada pelaksanaan kongres para pengurus menunjuk seorang pemimpin sesuai dengan hasil rapat. Seperti tulisan Nagazumi (1989) Dokter Wahidin Soedirohoesodo ditetapkan sebagai ketua kongres dan disetujui oleh seluruh tamu undangan (hlm. 65). Ketika rapat terselenggara Wahidin tetap mengutarakan beberapa dalihnya, bahwa seluruh masyarakat nusantara atau khususnya Jawa masih dipengaruhi sistem kasta Hindu, yaitu mengenal sistem kasta atau kelas. Meski demikian penyampaian Wahidin tetap menggunakan sikap soaial yang baik.

Kongres tersebut terdapat beberapa permasalahan yang muncul. Diantaranya adalah perbedaan pendapat dari beberapa usulan peserta kongres. Usulan dari golongan radikal yang seakan memojokkan perwakilan pejabat kompeni Belanda, terutama mengenai nasib masyarakat Indonesia selama masa penjajahan. Hal ini dapat ditengahi dengan sikap patuh nilai norma pemimpin rapat. Selanjutnya tanggapan dari pemerintah kolonial yang bijakpun muncul mewarnai kongres pertama tersebut.

Selanjutnya dapat diputuskan hasil kongres pertama organisasi pergerakan Boedi Oetomo, diantaranya adalah: (1) Pembentukan pengurus resmi organisasi pergerakan Boedi Oetomo; (2) Penetapan R.A.A Tirtokoesoemo sebagai ketua organisasi; (3) Perjuangan memperjuangkan 
nasib masyarakat Indonesia, khususnya di bidang sosial dan pendidikan.

Terdapat hal menarik pada hasil kongres pertama Boedi Oetomo untuk disimak, dari sembilan pengurus Boedi Oetomoitu tidak menyertakanpengurus lama seorang pun (Gamal Komandoko, 2008:66). Termasuk Soetomo yang sudah berjuang keras mendirikan dan memperjuangkan organisasi ini hingga menjadi besar. Hal ini disebabkan seluruh pengurus masih berstatus sebagai mahasiswa, masih banyak kwajiban yang perlu diselesaikan. Meski demikian semua pengurus menerima dengan lapang dada, bahkan mereka masih berlaku sopan dan menunjukkan sikap sosial yang baik.

\section{b. Kongres kedua Boedi Oetomo}

Kongres kedua organisasi pergerakan Boedi Oetomo dilaksanakan satu tahun setelah kongres pertama. Dilaksanakan di gedung Mataran Yogyakarta, pada tanggal 10 sampai 11 Oktober 1909 (Robert Van Neil, 1984:84). Peserta kongres kedua tidak sebanyak kongres pertama yaitu sebanyak 300orang. Undangan peserta kongres tidak hanya berasal dari masyarakat Indonesia, melainkan juga berasal dari orang China maupun orang Eropa.

Pada kongres kedua organisasi ini tidak seramai pelaksanaan kongres pertama. Hal ini disebabkan peserta rapat tidak hanya orang Indonesia, melainkan juga terdapat perwakilan asing yang ikut serta dalam pertemuan tersebut. Dengan demikian membuat ruang gerak kongres Boedi Oetomo hanya terbatas. Perlu kehati-hatian saat mengemukakan pendapat.

Pembahasan kongres kedua tersebut hanya seputar laporan pengurus Boedi Oetomo kepada peserta kongres. Kongres dipimpin langsung oleh ketua kongres, yaitu R.A. A Tirtokoesoemo dan didampingi beberapa pengurus yang lain. Dalam pertemuang kongres tersebut, membahas tentang bahasa persatuan organisasi pergerakan Boedi Oetomo dan laporan keuangan selama satu tahun menjabat sebagai pengurus organissi.

Pada kongres tersebut tidak tampak pengurus dan pendiri lama yang hadir. Membuat kongres tidak membahas tujuan awal didirikannya organisasi pergerakan Boedi Oetomo. Tidak tampak pembahasan tentang perubahan nasib bangsa Indonesia khususnya pada bidang sosial dan pendidikan. Tidak terdapat pembahasn tentang keinginan untuk memerdekakan bangsa Indonesia dari belenggu penjajahan. Dalam kongres ini hanya seputar pertemuan anatara pengurus organisasi dengan pejabat dan pejabat kompeni Belanda saja.

Hal ini sangat disayangkan bagi para anggota organisasi pergerakan Boedi Oetomo. Gagasan datang dari salah satu peserta kongres, Mohammad Tahir. Salah satu guru di Batavia, dalam sarannya menyatakan bahwa Boedi Oetomo hendaknya merekrut anggota dari kalangan bukan priyayi (Ricklefs, 2011:251). Apabila semua anggota organisasi dari kalangan priyayi maka organisasi tidak akan mendapat kemajuan.

Beberapa masukan dari kongres tersebut ditampung, selanjutnya diputuskan hasil kongres kedua organisasi pergerakan Boedi Oetomo, diantaranya adalah; (1) Penentuan bahasa Melayu sebagai bahasa pemersatu organisasi pergerakan Boedi Oetomo; (2) Permasalahan mengatasi kesulitan keuangan diselesaikan dengan dua cara, yaitu dengan tidak melaksanakan kongres ketiga organisasi pergerakan Boedi Oetomo dan meminta izin pejabat kompeni Belanda guna untuk melaksanakan undian penggalangan dana.

Keputusan kongres kedua organisasi pergerakan Boedi Oetomo sudah diambil, selanjutnya kongres diakhiri dengan putusan hambar atau tidak semua argumen atau usulan saat kongres disepakati sebagai hasil kongres. Putusan kongres kedua organisasi pergerakan Boedi Oetomo ini hanya berdasarkan keputusan dari pejabat kompeni Belanda dan selebihnya hanya sebagai usulan dalam kongres saja.

Perbedaan sangat tampak antara kongres pertama dan kedua organisasi pergerakan Boedi Oetomo. Hal ini dapat dilihat dari sikap anggota organisasi yang kontras antara kedua kongres. Pada kongres pertama tampak pembahasan mengenai nasib dan kemajuan bangsa Indonesia, sedangkan pada kongres kedua hanya seputar laporan organisasi kepda pemerintah kolonial, bahkan dalam keputusan kongres kedua hanya seizin pemerintah kolonial. 


\section{Sikap Sosial Anggota Organisasi pergerakan Boedi Oetomo}

Organisasi pergerakan Boedi Oetomo terdiri dari berbagi macam keanggotaan. Sejak awal pendirian organisasi ini didirikan oleh mahasiswa kedokteran STOVIA, yaitu dari latar belakang masyarakat cendekiawan. Dilanjutkan setelah kongres pertama organisasi ini dijalankan oleh golongan priyayi. Diantaranya adalah kaum terpelajar dan golongan masyarakat kelas atas.

Dalam pelaksanaan organisasi pergerakan Boedi Oetomo para anggota harus mempunyai sikap sosial baik, sebab organisasi ini menjadi salah satu organisasi terkemuka di hadapan pemerintah kolonial. Organisasi yang bergerak atas izin pejabat kompeni Belanda. Bahakan semua kegiatan dan perlakuan anggota dimonitori oleh pejabat kompeni Belanda.

Permasalahan ini menjadi fokus pembahsan sebab Boedi Oetomo adalah organisasi pergerakan pertama yang bertujuan untuk merubah nasib masyarakat Indonesia dari belenggu kolonial. Upaya besar dilaksanakan oleh pengurus organisasi. Dengan kehati-hatian dan sikap sosial yang baik hingga muncul sebuah organisasi besar.

Organisasi pergerakan Boedi Oetomo berkembang besar dengan dijalankan oleh para anggotanya. Anggota organisasi ini berjuang dengan kuat dan menitik beratkan pada sikap sosial. Pelaksanaan organisasi ini selalu berhadapan dengan pejabat kompeni Belanda sehingga harus mempunyai sikap sosial yang baik pula.

Sikap sosial merupakan kesadaran dalam diri individu terhadap lingkungan sosial di sekitarnya. Sikap sosial biasanya ditunjukkan karena adanya rasa perhatian dan kepedulian terhadap lingkungan dimana seseorang tersebut berada. Sedangkan sikap sosial dasar merupakan hal-hal atau sikap yang mendasari perkembangan sosial setiap individu. Sikap sosial dasar tersebut sebaiknya ditanamkan pada diri individu sejak usia dini. Dalam wacana yang bersifat umum, Baron dan Byrne (2004), mengemukakan definisi sikap sebagai penilaian subjektif seseorang terhadap suatu objek sikap.

Sikap sosial anggota organisasi pergerakan Boedi Oetomo sejak awal pendirian, yaitu dilaksanakan oleh para mahasiswa sudah terbukti baik. Selanjutnya setelah kongres pertama anggota organisasi yang mayoritas dari kaum priyayi tidak mungkin apabila mempunyai sikap sosial yang tidak baik. Setelah berbagai masalah dihadapi oleh anggota organisasi ini tetap dapat menjaga sikap sosial, bahkan dapat dijadikan panutan sebagai tokoh pelaksana dalam pergerakan nasional. Suatu pergerakan untuk merubah jati diri masyaraka Indonesia.

Dari pembahasan diatas, peneliti mencoba untuk memetakan sikap sosial yang dapat dilaksanakan anggota organisasi pergerakan Boedi Oetomo. Dasar pemetaan tersebut berdasarkan pedoman indikator sikap sosial dari studi historis organisasi pergerakan Boedi Oetomo terdapat delapan sikap sosial baik.

\begin{tabular}{c|l|l} 
No & \multicolumn{1}{|c|}{ Sikap Sosial } & Tindakan Anggota Organisasi pergerakan Boedi Oetomo \\
\hline 1. & Jujur & $\begin{array}{l}\text { Tokoh pendiri organisasi pergerakan Boedi Oetomo } \\
\text { melaksanakan kongres pertama sesuai dengan hasil rapat } \\
\text { koordinasi dengan anggota. }\end{array}$ \\
\hline 2. & Disiplin & $\begin{array}{l}\text { Seluruh anggota organisasi pergerakan Boedi Oetomo } \\
\text { melaksanakan kongres pertama tepat pada tanggal 3 } \\
\text { hingga 5 Oktober 1908 dan kongres kedua tanggal 10 } \\
\text { hingga 11 Oktober 1909. }\end{array}$ \\
\hline 3. & Tanggung Jawab & $\begin{array}{l}\text { Anggota Boedi Oetomo menjalankan semua hasil } \\
\text { kongres dan dilaporkan pada kongres berikutnya. }\end{array}$ \\
\hline 4. & Gotong Royong & $\begin{array}{l}\text { Para anggota organisasi pergerakan Boedi Oetomo saling } \\
\text { bekerja sama untuk merealisasikan hasil kongres. }\end{array}$ \\
\hline 5. & Emansipasi & $\begin{array}{l}\text { Pada saat pelaksanaan kongres dihadiri berbagai jenis } \\
\text { golongan masyarakat, namun tetap saling menghargai } \\
\text { anatara sau dengan yang lain. }\end{array}$ \\
\hline 6. & Percaya Diri & $\begin{array}{l}\text { Organisasi pergerakan Boedi Oetomo berawal dari } \\
\text { perkumpulan mahasiswa yang mempunyai tekat untuk } \\
\text { merubah masyarakat Indonesia. Berbagai macam cara } \\
\text { dilaksanakan para anggota sendiri guna mencapai tujuan. }\end{array}$
\end{tabular}




\begin{tabular}{c|l|l}
7 & Patuh nilai dan norma & $\begin{array}{l}\text { Semua anggota organisasi pergerakan Boedi Oetomo } \\
\text { selalu patuh terhadap peraturan dan menjaga sikap baik } \\
\text { sesama maupun kepada pemerintah kolonial. }\end{array}$ \\
\hline 8. & Sopan Santun & $\begin{array}{l}\text { Mayoritas anggota Boedi Oetomo berasal dari golongan } \\
\text { terpelajar dan para priyayi, sehingga semua tindakan } \\
\text { sudah disesuaikan dengan adat timur. }\end{array}$
\end{tabular}

Dari pemetaan diatas maka dapat ditemukan delapan sikap sosial baik, diantaranya jujur, disiplin, tanggung jawab, gotong-royong, emansipasi, percaya diri, patuh nilai dan norma, serta sopan santun. Temuan sikap tersebut berdasarkan kegiatan pergerakan organisasi pergerakan Boedi Oetomo selama menjalankan kegiatan.

Semua gambaran sikap sosial anggota Boedi Oetomo dapat dikategorikan baik. Suatu suri tauladan baik yang pantas dicontoh generasi masa kini. Generasi yang sudah terkena arus modernisasi dan globalisasi. Penerus bangsa yang baik hendaknya dapat meneladani perilaku terpuji para tokoh perjuangan bangsa dahulu.

\section{PENUTUP}

\section{Simpulan}

Hasil pembahsan sikap sosial anggota organisasi pergerakan Boedi Oetomo dapat dilihat dari pelaksanaan kegiatan. Terdapat delapan sikap sosial baik yang perlu dipahami dan dicontoh, diantaranya adalah jujur, disiplin, tanggung jawab, gotong-royong, emansipasi, percaya diri, patuh nilai dan norma, serta sopan santun. Perilaku yang dilaksanakan oleh para anggota organisasi tersebut dapat memberi suri tauladan terhadap masyarakat Indonesia saat ini. Boedi Oetomo adalah organisasi pergerakan nasional pertama yang dilaksanakan di Indonesia. Organisasi yang banyak memberikan aspirasi bagi seluruh masyarakat Indonesia yaitu untuk dapat merubah pola fikir dan sikap sosial. Selanjutnya berdasarkan pembahasan tentang sikap sosial anggota organisasi tersebut diharapkan dapat memberikan wawasan bagi para pembaca maupun bagi penerus bangsa agar dapat berlaku baik sesuai dengan sikap sosial anggota Boedi Oetomo.

\section{DAFTAR PUSTAKA}

Alfian, M. 2013. "Potensi Kearifan Lokal dalam Pembentukan Jati Diri dan Karakter Bangsa”. dalam Prosiding ICSSIS (International Conference on Indonesian Studies) di Yogyakarta Tanggal 13-14 Juni 2013.

Baron, R. A, Byrne, Donn. 2004. Psikologi Sosial 1. Edisi 10. Jakaerta: Erlangga

Komandoko, G. 2008. Boedi Oetomo, Awal Kebangkitan Nasional. Jakarta: Media Persindo.

2006. Kisah 124 Pahlawan dan Pejuang Nusantara. Yogyakarta: Pustaka Widyatama.

Kristanto, J.B. 2000. Seribu Tahun Nusantara. Jakarta: Kompas.

Larson, George D. 1990. Massa menjelang revolusi, Kraton dan Kehidupan Politik di Surakarta 1912-1942. Yogyakarta: UGM Press.

Nagazumi, A. 1989. Bangkitnya Nasionalisme Indonesia. Jakarta: Pustaka Utama Grafiti

Notosusanto, N, dkk. 1993. Sejarah Nasional Indonesia $V$. Jakarta: Balai pustaka

Ricklefs, M.C. 2011. Sejarah Indonesia Modern. Yogyakarta: Gajah Mada University Press

Van Neil, R. 1984. Munculnya Elit Modern Indonesia. Jakarta: PT Dunia Pustaka Jaya.

Wijayanti, Y. 2017. Peranan Penting Sejarah Lokal dalam Kurikulum di Sekolah Menengah atas. Ciamis: Jurnal Artefak Vol 4, No.l April 2017. Halaman 53-60 